\title{
Hanford Site Stream-Specific Reports
}

Waste Management Advanced

Effluent Technology Unit

Date Published

August 1990

Prepared for the U.S. Department of Energy Office of Environmental Restoration and Waste Management

(2) Westinghouse $\begin{aligned} & \text { P.O. Box } 1970 \\ & \text { Hanford Company }\end{aligned}$

Hanford Operations and Engineering Contractor for the

U.S. Department of Energy under Contract DE-AC06-87RL10930

Approved for Public Release

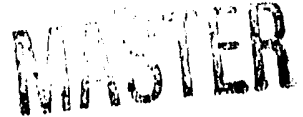


Document Title:

Approved by:

Approved by:
HANFORD SITE STREAM-SPECIFIC REPORTS

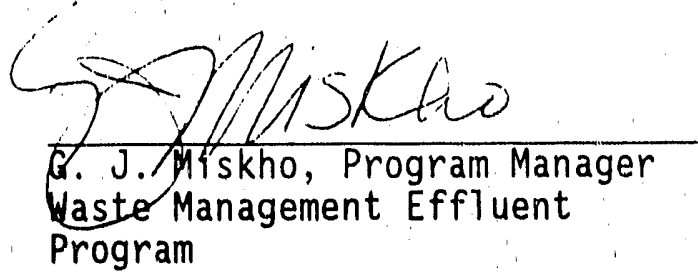

DaFurer

D. A. Turner, Manager

Program Integration 
WHC-EP-0342

HANFORD SITE STREAM-SPECIFIC REPORTS

Waste Management Advanced Effluent Technology Unit

\section{ABSTRACT}

This document and the associated 33 stream-specific addenda were prepared in response to public comments received on the Hanford Federal Facility Agreement and Consent Order.* The processes used to characterize the effluents and propose designations pursuant to the Washington (State). Administrative Code 173-303, Dangerous Waste Regulations**, are described in this "parent" document. A combination of process knowledge and sampling data was used to accomplish these tasks.

*Ecology, EPA, and DOE, 1989, Hanford Federal Facility Agreement and Consent Order, Washington State Department of Ecology, U.S. Environmental Agency, and the U.S. Department of Energy, 0lympia, Washington. $\star \star E c o l o g y, 1989$, Dangerous Waste Regulations, Washington (State) Administrative Code (WAC) 173-303, Washington State Department of Ecology, Olympia, Washington. 
WHC - EP-0342

\section{EXECUTIVE SUMMARY}

During the development of the Hanford Federal Facility Agreement and Consent Order*, public comments were received regarding reduction of the discharge of liquid effluents into the soil column. To address these comments, the U.S. Department of Energy (DOE), with concurrence of the Washington State Department of Ecology (Ecology), and the U.S. Environmental Protection Agency (EPA), committed to document the discharge history, characterize the liquid discharge, and assess the potential for and extent of contamination in soils and groundwater.

This document describes the process associated with the characterization of liquid effluents that discharge to the soil column on the Hanford Site. The program utilizes both process knowledge and sampling data to characterize the effluent and to propose a designation based upon requirements in the Dangerous Waste Regulations.** The characterization information and designations for the 33 1iquid effluent streams on the Hanford Site are documented in the attached stream-specific reports.

*Ecology, EPA, and DOE, 1989, Hanford Federal Facility Agreement and Consent Order, Washington State Department of Ecology, U.S. Environmental Agency, and the U.S. Department of Energy, 0lympia, Washington. **Ecology, 1989, Dangerous Waste Regulations, Washington (State) Administrative Code (WAC) 173-303, Washington State Departinent of Ecology, 01 ympia, Washington. 


\section{CONTENTS}

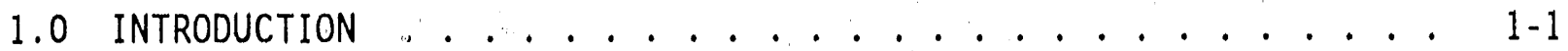

1.1 OVERVIEW . . . . . . . . . . . . . . . . 1-1

1.2 PURPOSE . . . . . . . . . . . . . . . 1-1

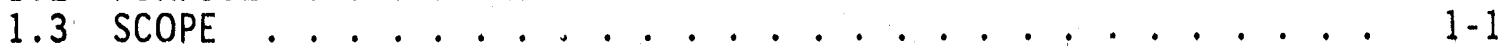

1.4 DOCUMENTATION . . . . . . . . . . . . . . . . . . . . .

2.0 CHARACTERIZATION--PROCESS KNOWLEDGE ........... 2-1

2.1 PHYSICAL LAYOUT ..................... 2- . . .

2.2 PROCESS CONTRIBUTORS ............... 2-1

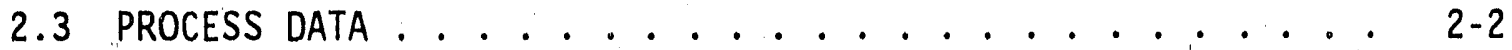

3.0 CHARACTERIZATION--EFFLUENT SAMPLING . . . . . . . . . 3-1

3.1 SAMPLE COLLECTION ..................... $3-1$

3.2 SAMPLE ANALYSIS . . . . . . . . . . . . . . $3-1$

3.3 DATA PRESENTATION . . . . . . . . . . . . $3-2$

4.0 CHARACTERIZATION OVERVIEW . . . . . . . . . . . . 4-1

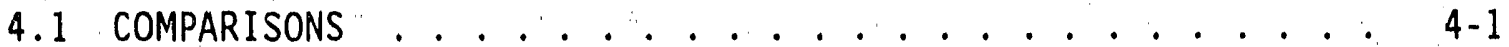

4.2 DEPOSITION RATES ...................... . . . . .

5.0 WASTESTREAM DESIGNATION PROCEDURE . . . . . . . . . 5-1

5.1 SAMPLE DATA SCREENING . . . . . . . . . . . . . . 5-1

5.2 DANGEROUS WASTE LISTS ................ . . . . $5-3$

5.2.1 Discarded Che lical Product . . . . . . . . . . . . 5-7

5.2 .2 Dangerous Wa te Sources . . . . . . . . . . . 5-9

5.3 DANGEROUS WASTE CRI IERIA . . . . . . . . . . . . . 5-9

5.3.1 Toxic Dangerous Waste . . . . . . . . . . . . . . 5-10

5.3.2 Persistent Dangerous Waste ......... 5-10

5.3.3 Carcinogenic Dangerous Waste .......... 5-11

5.4 DANGEROUS WASTE CHARACTERISTICS .......... 5-12

5.4 .1 Ignitability .............. 5-12

5.4 .2 Corrosivity. . . . . . . . . . . . 5-12

5.4.3 Reactivity ............... 5-12

5.4.4 Extriction Procedure Toxicity. . . . . . . . 5-13

5.5 PROPOSED DESIGNATION . . . . . . . . . . . . . . 5-13

6.0 ACTION PLAN ..................... 6-. . . .

7.0 REFERENCES ................... . . 7-1 APPENDIXES:

A Sampling Specifications..................A-1

B. Methods of Analysis . . . . . . . . . . . . . . . . B-1

C Screening Values Used in Effiuent Comparisons . . . . . . . . . C-1 
WHC -EP-0342

\section{LIST OF FIGURES}

5-1 Designation Procedure ............... 5-2

\section{LIST OF TABLES}

1-1 Stream-Specific Characterization Reports . . . . . . . 1-2

5-1 Summary of Volatile Organic Analysis Blank Data........ 5-1j

5-2 Sample Blank Threshold Values............. 5-5

5-3 Sanitary Water Threshold Values . . . . . . . . . . 5-8 
WHC-EP-0342

HANFORD SITE STREAM-SPECIFIC REPORTS

\subsection{INTRODUCTION}

\subsection{OVERVIEW}

During the development of the Hanford Federal Facility Agreement and Consent Order (Tri-Party Agreement) (Ecology et al. 1989), comments from the public were received regarding the discharge of liquid effluents into the soil column. As a result, the U.S. Department of Energy (DOE), with concurrence of the Washington State Department of Ecology (Ecology) and the U.S. Environmental Protection Agency (EPA), committed to document the discharge history, characterize the liquid discharge, and assess the potential for and extent of contamination in soils and groundwater (Lawrence 1989).

This effort is described in the Liquid Effluent siudy Project Plan (WHC 1990a). The results of the assessment will be utilized to determine the need for revising the current plan for eliminating discharges of contaminated liquid effluents to the soil column. A portion of this study (WHC 1990a) consists of characterizing 33 key liquid effluent streams on the Hanford Site--the focus of this report.

\subsection{PURPOSE}

This document describes the process that was used for characterizing and designating liquid effluents that typically discharge to the soil column on the Hanford Site. The program utilizes both process knowledge and sampling data to characterize the effluent and to propose a designation based upon requirements in Ecnlogy's Dangerous Waste Regulations, Washington (State) Administrative Code (WAC) $173-303$ (Ecology 1989). The characterizations and designations for the 33 liquid effluent streams on the Hanfoid Site are documented in the attached stream-specific reports (Addenda 1 through 33 ). This lead-in, or "parent" document, is patterned after the format used in these addenda to facilitate their interpretation.

\subsection{SCOPE}

The characterization effort addresses the 19 Phase I and 14 Phase II streams identified in the 1989 Annual Status Report of the Plan and Schedule to Discontinue Disposal of Contaminated Liquids into the Soil Column at the Hanford Site (Millikin 1989). These effluent streams and their corresponding addenda numbers are listed in Table 1-1. This document does not address other sections of the Liquid [ffluent Study Project Plarl (WHC 1990a) such as groundwater characterization and flow and transport characteristics. Those subjects are included in the Liquid Effluent Study Final Project Report (WHC 1990d). 
WHC -EP-0342

Table 1-1. Stream-Specific Characterization Reports.

\begin{tabular}{|c|c|c|}
\hline 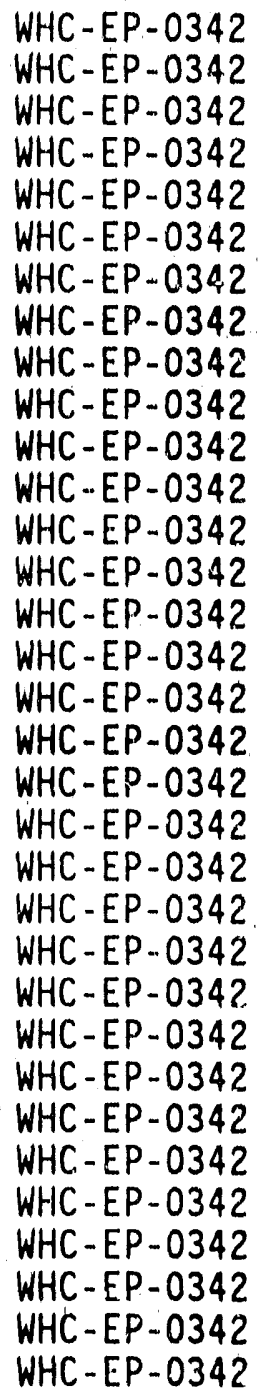 & $\begin{array}{l}\text { Addendum } 1 \\
\text { Addendum } 2 \\
\text { Addendum } 3 \\
\text { Addendum } 4 \\
\text { Addendum } 5 \\
\text { Addendum } 6 \\
\text { Addendum } 7 \\
\text { Addendum } 8 \\
\text { Addendum } 9 \\
\text { Addendum } 10 \\
\text { Addendum } 11 \\
\text { Addendum } 12 \\
\text { Addendum } 13 \\
\text { Addendum } 14 \\
\text { Addendum } 15 \\
\text { Addendum } 16 \\
\text { Addendum } 17 \\
\text { Addendum } 18 \\
\text { Addendum } 19 \\
\text { Addendum } 20 \\
\text { Addendum } 21 \\
\text { Addendum } 22 \\
\text { Addendum } 23 \\
\text { Addendum } 24 \\
\text { Addendum } 25 \\
\text { Addendum } 26 \\
\text { Addendum } 27 \\
\text { Addendum } 28 \\
\text { Addendum } 29 \\
\text { Addendum } 30 \\
\text { Addendum } 31 \\
\text { Addendum } 32 \\
\text { Addendum } 33\end{array}$ & 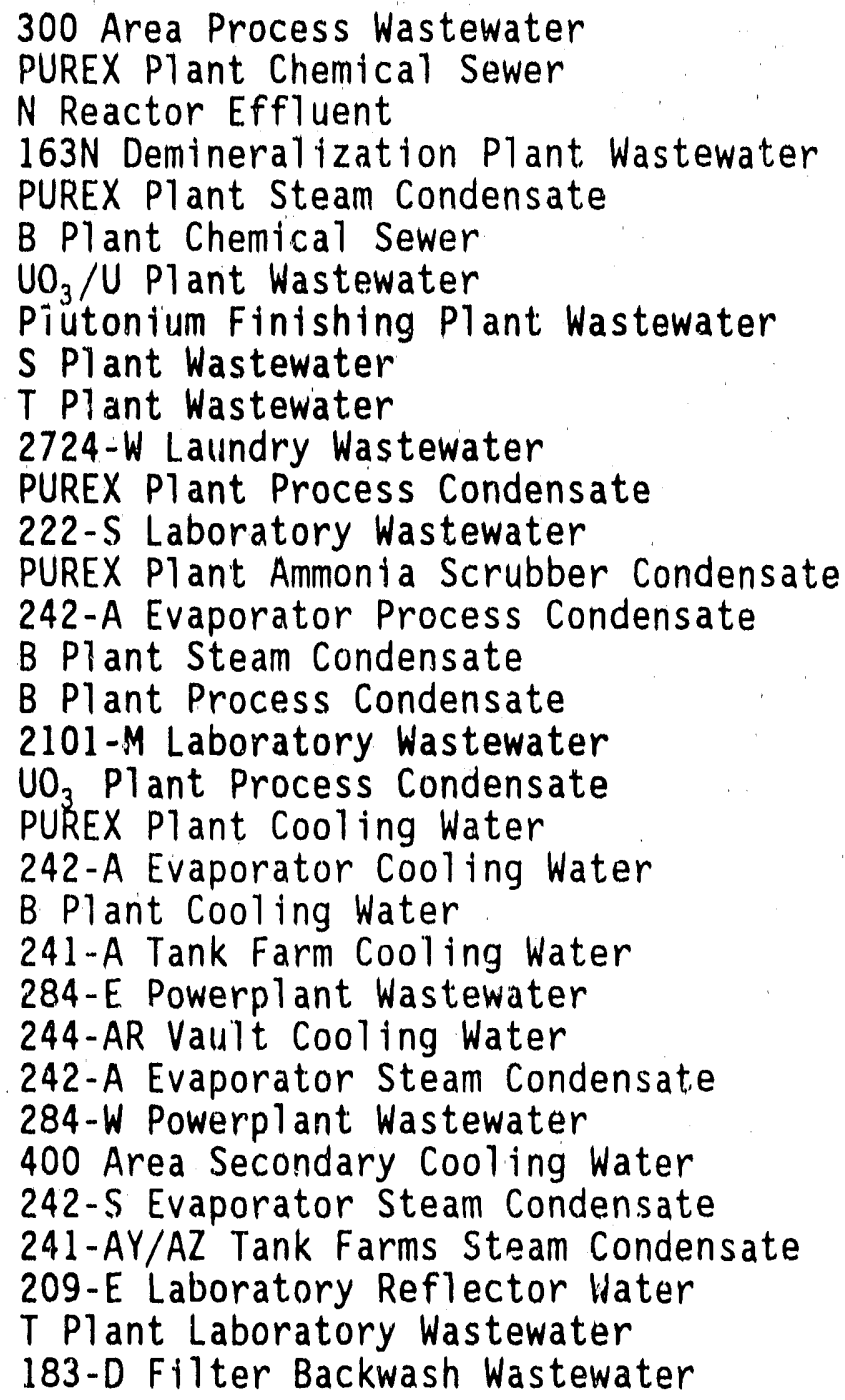 \\
\hline
\end{tabular}


The database used in each addendum for designation purposes and other evaluations is selected to present the most up-to-date condition for the effluent. In most cases this consists of sample data collected during the October 1989 through March 1990 pertod associated with the Liquid Effluent Study Project Plan (WHC 1990a) or "new data." New data are avallable for 24 of the 33 effluents. Data collected prior to October 1989, or "old data," are used for the remaining nine effluents.

\subsection{DOCUMENTATION}

Apart from the subject 33 addenda of this report, additional documents supporting the characterization of the liquid effluents are 1isted and briefly described below:

- Liquid Effluent Study Project Plan, WHC-EP-0275 (WHC 1990a)--This plan describes the activities to be accomplished during the groundwater characterization and effluent characterization phases of the liquid effluent study.

- Waste Stream Characterization Report, WHC-EP-0287 (WHC 1989)--This report provides background information on the effluents and receiving sites. The four volume set covers both historical data (through July 1989) and the plan for additional sampling and effluent evaluation. Much of the same material has now been factored into the Liquid Effluent Study Final Project Report, WHC-EP-0367 (WHC 1990d), as well as into this report.

- Wastestream Designation of Liquid Effluent Analytical Data, WHC-EP-0334 (WHC 1990b)--This report contains a description of how the sainpling data are appraised and then subsequently used as a screening tool to evaluate each wastestream.

- Liquid Effluent Study Characterization Data, WHC-EP-0355 (WHC 1990C)--This report contains all results from the analys is of liquid effluent samples collected between October 1989 and March 1990 and was issued as a supplement to the preliminary stream-specific reports (SSR). These data, except for some below detection limit results (see Section 3.3), have now been incorporated into the appended, final SSRs. 
WHC-EP- 0342

\subsection{CHARACTERIZATION--PROCESS KNOWLEDGE}

The wastestream characterization effort is gutded by process knowledge and the results of sampling and analysis programs. The results of this effort are documented in the appended 33 stream-specific reports. A brief description of the process knowledge portion of characterization is covered in this section. The process evaluation includes a description of the current physical layout of the overall effluent system, a discussion of activities contributing to the discharge, and the presentation of process data.

\subsection{PHYSICAL LAYOUT}

A schematic flowsheet or block diagram showing the general layout of the generating complex, as it relates to the effluent, provides a focus of discussion in each report. The figures include major sources (or contributors), monitor locations, location for samples collected by the SSR effort, diversion factlities, and the final discharge poin'. These figures are intended to document the physical condition of the system during the October 1989 through March 1990 timeframe.

In addition to revealing the current process monitor locations on the schematic, a discussion of the purpose and type of process monitors (pH, radionuclides, flow, chemical constituents), their limits (e.g., ranges, detection levels, etc.), and how the monitoring system will detect and respond to process upsets is included.

Past configurations are also discussed which either support the evaluation of old data, demonstrate the impact of subsequent modifications, or help explain the current design detalls. These discussions are central to the understanding of effluents which are currently inactive and usually provide benefictal insight into the structure of active streams.

Process changes or alterations that are anticipated to occur within the facility or complex generating the wastestream are also highlighted. If there is no firm funding commitment for modifications which could have a significant impact on the effluent, the document still includes them but states the funding status. Tri-Party Agreement (Ecology et. a1. 1989) M-17 milestones are aiways mentioned as appropriate. In addition, future modifications which are contingent upon funding commitments are listed.

\subsection{PROCESS CONTRIBUTORS}

Once the physical layout of the system has been described, the processes which produce the flow and contribute to its chemical makeup and physical properties are assessed. Once again the focus is on the current process configuration or situation (1.e., October 1989 through March 1990), supplemented by discussions of relevant past and planned future activities. 
The evaluation of the processes that contribute to the wastestream typically includes a review of the following:

- Superfund Amendments and Reauthorization Act (SARA) Inventory Reports

- Material Safety Data Sheets on inventoried chemicals

- Operating procedures

- Spill history documented in the Waste Stream Characterization Report (WHC 1989)

- Process flowsheets and chemical inventories

- Physical inspections, when needed and where possible.

Some analytical data, other than from effluent samples, also fit into the category of process knowledge, such as analytical information on feed chemical impurities and supply waters. The supply waters carry contaminants introduced within the process and are a background source for many const 1 tuents found in the effluent. There are several types of supply water $(\mathrm{e} . \mathrm{g}$. , raw water, usually just screened and clarified; sanitary or potable water usually filtered and chlorinated raw water; demineralized water, usually treated for process requirements by ion exchange; and steam condensate modified for use prior to steam generation at the powerhouses).

\subsection{PROCESS DATA}

Sections 2.1 and 2.2 present the types of constituents to expect (and sometimes their concentration ranges), the probable flow magnitude and variations, the key contributors, and the logical location for obtaining representative samples. In addition, enough information was available for a few effluents to permit the estimation of likely, simulated sample analysis results. When avallable, these engineering estimates are compared with actual sample data in Section 4.0 of the affected addenda. Section 4.0 of this document similarly explains these and other comparisons.

The process evaluation was also an integral part of determining whether the effluent stream should be designated. For example, if a listed constituent was detected at the sampling point, the stream would not be regulated if a knowledge of upstream activities is sufficient to demonstrate that proper practices were in effect. This application of process knowledge is discussed in Section 5.0 of this report and the associated, individual SSR addenda. 


\subsection{CHARACTERIZATION--EFFLUENT SAMPLING}

An evaluation of the wastestream through sample collection and analys is was utflized to enhance and support the results of the previously discussed process evaluation. Major components of the sampling regime for this project include sample collection, sample analysis, and data presentation. A brief description of these components is presented in the sections that follow.

\subsection{SAMPLE COLLECTION}

Representative samples of all discharges as described in the Waste Stream Characterization Report (WHC 1989) were obtained. The samples were typically collected downstream of all contributors, with a few exceptions such as some additional upstream sampling done before October 1989 in the 300 Area. Any fatlure to obtain such downstream samples is addressed in the relevant SSR (see Section 6.0). The sampling, sample preservation, chain-of-custody, and documentation procedures employed were in accordance with EPA protocol SW-846 (EPA 1986a). Appendix A lists the various containers collected for each requested analysis. A matrix table is provided in each addendum stating which analyses were performed for each set of samples. Trip blanks and transfer blanks, in most cases, were also prepared and submitted to the contract laboratory. Blanks are discussed in more detail in Section 5.2.

Samples were collected for some streams at several locations due to the physical layout and multiple operating configurations. Not a 71 samples were taken at all points because not all configurations were operating. The sample locations and configurations are specified in each addendum. The same locations were used for samples collected before and after October 1989, with one exception, the PUREX Plant process condensate (Addendum 12).

\subsection{SAMPLE ANALYSIS}

Because specific environmentally significant constituents are rarely known in advance, the characterization program relies on a large number of analyses performed on a limited rumber of samples. The majority of the anaiyses were performed in accordance with EPA protocol SW-846. Additional methods were adopted as needed and include:

- Other EPA methods (e.g., alpha counting)

- Standard analytical methods (e.g., suspended solids)

- American Society for Testing and Materials method(s) (e.g., fluoride by ion-specific electrode)

- Contract laboratory methods (e.g., direct aqueous injection by gas chromatography). 
Information pertaining to specific methods utilized in the sample analysis is presented in Volume 4 of the Waste Stream Characterization Report (WHC 1989). Contract laboratory detection limits (subject to change over time) are located in Vclume 1 of the report. Available analytical methods were used for all analytes. Additional methods were used as they became available. A listing of the procedures currently in use is contained in Appendix B.

The analytical data received from the contract laboratory typically include: sample number, procedure code, analyte code, sample date, analysis date, and analytical result. The data are then reformatted in a "userfriendly" format, which is presented in the addenda. One aspect of this format change is to identify related sample sets by keying off the primary sample number and using the suffixes "B" for trip blanks, "T" for transfer blanks, and " $E$ " for extracts. This is addressed in greater detail in the Liquid Effluent Study Characterization Data report (WHC 1990C).

The procedure developed by the Westinghouse Hanford Company (Westinghouse Hanford) for managing the sample data is discussed in the Wastestream Designation of Liquid Effluent Analytical Data report (WHC 1990b). The procedure replaces less-than detection 1 imit data and eliminates replicate results for a single analyte according to methods described in the report.

The new data have been validated according to an internal Westinghouse Hanford Company (Westinghouse Hanford) procedure which assesses the overall quality of the data and laboratory performance. This procedure has been derived largely from EPA guidance per the Laboratory Data Validation Functional Guidelines for Evaluating Organic. Analyses (EPA 1988a). It is also heavily based upon SW-846 methodology and Quality Control (QC) requirements (EPA 1986a). The "raw" laboratory data are reviewed individually, for parameters such as holding time exceeded (between collection and analysis), and in groups, for indicators involving analytical blanks and other laboratory QC checks.

The impact of validation on the new data was minimal. Three Acid Base Neutral (ABN) values were deleted--all were below detection limits; three Volatile Organic Analysis (VOA) values were changed--both the old and revised results were all below detection limits; and one Inductively Coupled Plasma (iCP) datum value was changed from $22 \mathrm{ppb}$ to $<22 \mathrm{ppb}$. There was no impact, as a result of validation, on any subsequent data evaluations.

\subsection{DATA PRESENTATION}

Statistical summary data for all new data (or old data in nine reports) taken for a given configuration are supplied in Section 3.0 of each report. The table includes "truncated" data showing: the number of analyses performed, the number of below detection limit (BDL) results, the method used to handle the BDL data, the mean, the standard error, the limit of a 
one-tailed $90 \%$ confidence interval ( $90 \% \mathrm{CI}$ ), and the "extreme" value (maximums for most, minimums for ignitability, and whichever end of the $\mathrm{pH}$ range is furthest from the center of the regulatory thresholds of 2 and 12.5). The $90 \%$ I was selected as the appropriate level to compare to regulatory thresholds, which is in accordance with guidance provided in SW-846 (EPA 1986a). The details of the statistical analysis are provided in the Wastestream Designation of Liquid E:fluent Analytical Data report (WHiC 1990b).

The truncated data provided in all SSRs and used in the designation process include all uncensored data and all censored values for analyte data sets that contain at least one detected (uncensored) value and all characteristic data for ignitability, reactivity, and extraction procedure (EP) toxicity. Results for characteristics are reported by the analytical laboratory as censored values when they are less than the limits of WAC 173-303-090 (Ecology 1989). This data set truncation is explained in more detail in the Liquid Effluent Study Characterization Data report (WHC 1990C).

The summary tables in the addenda are from the latest SSR sampling effort for new data (taken between October 1, 1989 and March 30, 1990), when it is available. Similar summaries are provided for the old data when it is used as a default for the nine unsampled effluents. To provide more complete information, the old data for the other 24 effluents also appear in a total data appendix contained within the relevant SSR. 
WHC-EP-0342

\subsection{CHARACTERIZATION OVERVIEW}

There are several reasons and techniques to compare characterization data obtained through both process knowledge and effluent sampling, both against each other and against various screening levels. Section 4.0 discusses the subject of data evaluations which are not related to proposed waste designations; proposed waste designations are discussed in Section 5.0.

\subsection{COMPARISONS}

Each SSR compares the average constituent concentrations to various screening values (Appendix $C$ ). These comparison guides, while derived from regulatory criteria, are not used here for compliance nurposes. The criteria apply to drinking water [the Maximum Contaminant Leve1; (MCL)] and to the Derived Concentration Guides (DCG). This comparison is an indicator of the likely availability of treatment technology capable of allowing further reductions in concentration.

A few of the addenda contain, within this section, a qualitative comparison between characterizations based upon Section 2.0 process knowledge and Section 3.0 sample data. This can also include a comparison between effluent and supply water composition. These match-ups can help demonstrate the representativeness of sampling and/or the degree of process knowledge available. For example, if, upon sampling, one does not encounter the constituents or levels predicted to be in the effluent, it could indicate a poor sampling location, an insufficient number of grab samples taken, a problem with sample preservation or analysis, or incomplete process knowledge. Similarly, the unexpected detection of constituents indicates a failure either to identify all contributors, to understand all the process parameters generating the waste, or some factor associated with the sample data.

\subsection{DEPOSITION RATES}

One typical measure used to evaluate a wastestream is the loading or total quantity of each constituent being discharged within a given time period. In each SSR, sample concentration data from Section 3.0 are converted to kilograms or curies per month (or per event for random, batch operations), using flow data or estimates presented in Section 2.0. This information was included for later use in deciding how streams may be prioritized with respect to needed treatment or changing the disposal site.

The term "deposition rate" is used instead of "loading" since loading implies a measure of the total release to the soil column receiving site. Because the sample data are tied directly to the effluent, rather than the disposal site, this assumption may not be valid. For example, an effluent could be diverted downstream of a sample point and subsequently treated or re-routed such that a given disposal site might not receive this loading. Other impacts downstream of sampling could include losses because of settling, plate-out, or evaporation. 
The deposition rates (as well as the screening value comparisons) are calculated (or performed) using only new data when avallable, as this effort is most interested in the condition of the currently active effluents. 01d data are used to supply deposition rates for the nine effluents not recentiy sampled. 


\subsection{WASTESTREAM DESIGNATION PROCEDURE}

The procedure discussed in Section 5.0 utilizes process and sample data to propose a waste designation in accordance with the Dangerous Waste Regulations (Ecology 1989). The mettiods used to reconcile the available laboratory data against the constraints imposed by the regulations are reviewed. Also described is the procedure followed in individual SSR potential listed waste determinations.

The procedure utilized in the characterization program for proposing a designation (in accordance with WAC 173-303) is illustrated in Figure 5-1. The procedure is based on the following:

- Dangerous Waste Lists (WAC 173-303-080)

- Dangerous Waste Criteria (WAC 173-303-100)

- Dangerous Waste Characteristics (WAC 173-303-090).

The designations presented in the addenda are relevant to the wastestreams as they currently exist (except for those which no longer discharge to the soll column). For streams which no longer discharge to the soil column, the designations are based on conditions at the time of the most recent, relevant sample collection. Inactive effluents and/or effluents currentiy routed to double-shell tanks will be characterized and designated upon startup or the resumption of a soll column discharge.

The designation of 1 isted waste is based on a combination of process knowledge (see Section 2.3) and sampling data (see Section 3.3). While new data forms the basis for 24 SSRs, sampling data collected between 1985 and July 1989 are considered when relevant to the characterization of the wastestreams as they presently exist. Sampling data only are compared to the dangerous waste criteria and dangerous waste characteristics for these portions of the designation process.

The following sections provide a brief discussion of the method and assumptions utilized for proposing the designations contained in the 33 addenda to this document.

\subsection{SAMPLE DATA SCREENING}

A procedure (WHC 1990a) developed for use as a screening tool in evaluating a wastestream lists possible combinations of cations and anions. These combinations, along with the organic constituents, were compared with the dangerous waste 1 ists. This screening method was not intended to be an indication that the substance was discharged to the wastestream but, rather, that the necessary cations and anions were present and that a process evaluation should be conducted to determine how they entered into the wastestream. 
Figure 5-1. Designation Procedure.

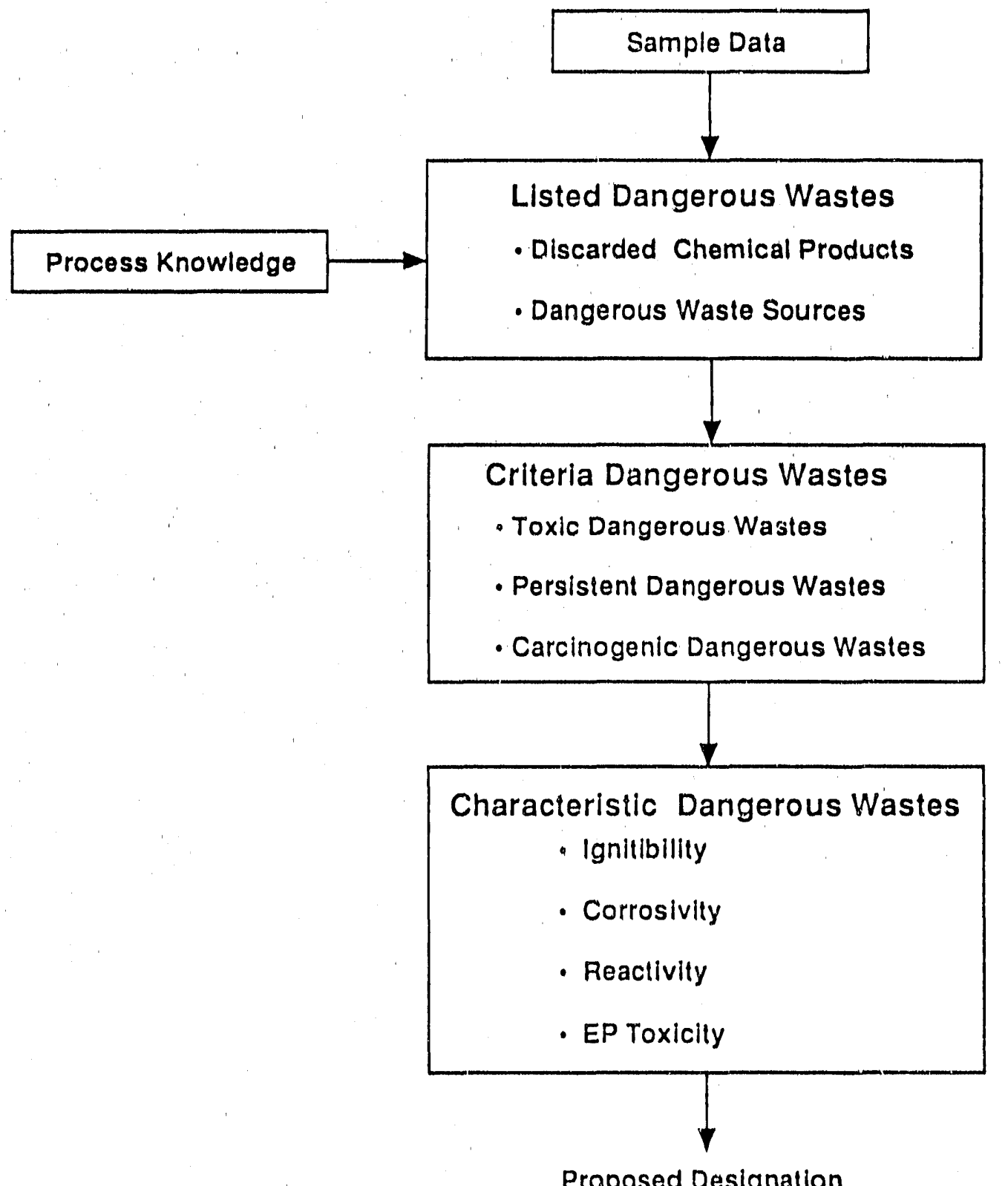

29004107.7 
The analytical data for organic constituents were reported and were directiy compared against the dangerous waste and dangerous waste source 1ists. Inorganic substances were reported as ions and could not be directiy compared to these lists. For example, an analysis might have shown a wastestream to contain the cations sodtum and calctum and the anions chloride and nitrate. The possible list of substances in this example includes sodium chloride, sodium nitrate, calclum chloride, and calcium nitrate. In an actual wastestream sample with many cations and anions, the list of possible combinations is extensive.

Each report contains an inorganic chemistry report table that depicts the process used to assign ion analytes to neutral substances which are required for designation. The table accounts for both the charge balancing of the ion assemblage (from the statistical summary tables discussed in Section 3.3) and the subsequent iormulation of neutral substances. A detalled discussion can be found in WHC-EP-0334, Wastestream Designation of Liquid Effluent Analytical Data (WHC 1990b).

\subsection{DANGEROUS WASTE LISTS}

A wastestream was regulated under WAC 173-303 if it either contained a discarded chemical product (WAC 173-303-081) or came from a dangerous waste source (WAC 173-303-082). The proposed designations were based on a combination of process knowledge and sampling data.

Detailed searches constitute the heart of any potentlal listed waste evaluation. The appearance of constituents in the sample results that could infer a listed waste may be explained in one of three ways (if nondesignated): (1) it is shown to be totally absent from the generating facility; (2) it is shown to be (or temporarlly was) present but excluded (by administrative means or physical barriers) from improper introduction into the effluent; or (3) it is not used in a manrier described in WAC 173-303-9904. Each SSR attempts to describe in sufficient detail what was done to demonstrate that all reasonable and appropriate actions were taken to address each issue. Examples of detafled search actions are questionnaires, plant employee interviews, and unusual occurrence reviews. Discussions with appropriate facility personnel determined if there were processes (e.g., cleaning of equipment with 1 isted solvents, laboratory processes, etc.) which may have resulted in the generation of ifsted waste and may not have been identified during other portions of the process evaluation.

In conjunction with the previously described detalled search, a discussion of an alternative reason for the detection of the analyte in the sample will add support to the potential 11sted waste explanation. Use of supply (or background) water data and/or blank data falls into this latter category of discussion. Use of these data will supplement, but not replace, a detalled search. The following general criteria have been established for the use of blank and supply water data. If specifics particular to a stream are more applicable than the general guidance, they are utilized rather than the general guidance. 


\section{BLANKS}

Approximately 180 trip and transfer blanks were collected and analyzed for volatile organics during the period between October 1989 and March 1990. Trip blanks are aliquots of "analyte-free" water brought to the fleld in sealed containers, kept closed, and transported back to the laboratory with the sample containers. The transfer blank is handled identically to the trip blank with the exception that the sealed (but empty) transfer blank bottle is opened in the field atmosphere and filled from a sealed bottle of the same type water originally used in the trip blank.

Organic constituents were noted to be present, as summarized in Table 5-1, in between 8 to 36\% of the trip and transfer blanks, depending upon the constituent. This type of volatile organics contamination in blanks is a common laboratory occurrence (EPA 1988a). The EPA guidance for handling this is that no positive sample results should be reported unless the concentration of the compound in the sample exceeds 10 times the amount in any blank for common contaminants (i.e., acetone, 2-butanone, and dichloromethane), or 5 times the amount for other compounds (EPA 1988a).

The EPA guidance relative to the multiple (5 times or 10 times) of the average was not considered conservative for use in screening potential problem streams. As a result, an alternate statistical approach was chosen rather than utilization of the EPA guidance. This approach also maintained statistical consistency within the report. A comparison between the results of the two methods is shown in Table 5-2. As the table shows the EPA guidance consistently results in a higher threshold.

Several detailed statistical approaches are avallable for the analysis of data. A normal distribution was used to develop a threshold value. This assumption was also employed for the sample data and is consistent with SW-846 guidance for small data sets (EPA 1986a). This SSR threshold value was used to separate analytical results due to sample contamination from results that likely reflect the actual effluent concentrations.

As shown in Table 5-1, there is a similar frequency of positive detections in the trip and transfer blanks. The use of all blank, versus just trip blank, averages makes itttle numerical difference (1.e., field contamination appears to be unlikely), while it does increase the size of the database drawn upon for trend information. In the SSR addenda, aS applicable, the upper 1 imit of the one-sided $90 \%$ confidence interval (90\%CI) of the mean positive blank concentration for the trip and transfer blanks has been used as a screening tool for certain constituents which were consistently seen in blank samples. This SSR threshold value establishes a level below which $90 \%$ of the means calculated for any number of repeat testing sets would fall. It is used here to indicate wastestream sample results which appear to be present due to sample contamination. 
WHC-EP-0342

Table 5-1. Summary of Volatile Organic Analysis Blank Data.

\begin{tabular}{|c|c|c|c|c|c|c|}
\hline Constituent & $\begin{array}{l}\text { Trip } \\
N \text {-det }\end{array}$ & $\begin{array}{l}\text { lanks } \\
\text { Avg. }\end{array}$ & $\begin{array}{l}\text { Transfe } \\
N-\operatorname{det}\end{array}$ & $\begin{array}{c}\text { Blanks } \\
\text { Avg. }\end{array}$ & $\begin{array}{l}A 11 \\
N-\operatorname{det}\end{array}$ & $\begin{array}{l}\text { anks } \\
\text { Avg. }\end{array}$ \\
\hline $\begin{array}{l}\text { Acetone } \\
\text { 1-Butanol } \\
\text { 2-Butanone (MEK) } \\
\text { Dichloromethane } \\
\text { Tetrahydrofuran }\end{array}$ & $\begin{array}{r}8 \\
8 \\
16 \\
31 \\
19\end{array}$ & $\begin{array}{r}20 \\
16 \\
21 \\
318 \\
14\end{array}$ & $\begin{array}{r}6 \\
10 \\
11 \\
34 \\
4\end{array}$ & $\begin{array}{r}17 \\
17 \\
24 \\
292 \\
12\end{array}$ & $\begin{array}{l}14 \\
18 \\
27 \\
65 \\
23\end{array}$ & $\begin{array}{r}19 \\
16 \\
22 \\
304 \\
14\end{array}$ \\
\hline
\end{tabular}

Notes:

$\mathrm{N}$-det = Total number of values above detection $1 \mathrm{imit}$.

Avg. = The average of the detected values, in $\mathrm{ppb}$.

For process samples in which volatile organics were noted, the following protocol was applied to determine if the organic could actually be present in the sample.

1. A review of chemical inventories and material management procedures at the facility was performed to evaluate potential sources of the detected constituent.

2. Individual sample results for a given constituent were compared to the SSR threshold value for blanks analyzed during that campatgn. Sample results less than this upper limit of the one-sided $90 \% \mathrm{CI}$ value for the blanks in which the constituent was detected were considered suspect due to the potential for contamination of the samples.

Based upon this protocol, data for common organic sample contaminants in individual samples which are greater than the SSR threshold values in Table 5-2 were considered substantive subject to further confirmation from facilityspeciftc information. Those falling below the threshold values, when no source of the detected constituent was identified, were attributed to sample contamination.

Table 5-2. Sample Blank Threshold Values.

\begin{tabular}{|l|c|c|c|r|r|}
\hline \multirow{2}{*}{ Constituent } & N & Avg. of & Standard & \multicolumn{2}{|c|}{ Threshold Values } \\
\cline { 5 - 6 } & & Blanks & Deviation & EPA & SSR \\
\hline Acetone & 14 & 19 & 10 & 190 & 37 \\
1-Sutanol (MEK) & 18 & 16 & 10 & 80 & 33 \\
2-Butanone (MEK) & 27 & 22 & 22 & 220 & 59 \\
Dichloromethane & 65 & 304 & 505 & 3040 & 1147 \\
Tetrahydrofuran & 23 & 14 & 4 & 70 & 21 \\
\hline
\end{tabular}

Note: Above detection $11 \mathrm{mit}$ results for samples taken between October 1989 and March 1990. All values (but N) in ppb. $90 \% C I=90 \%$ Confidence Interval. $\mathrm{N}=$ number of datected results. 
WHC-EP-0342

\section{SUPPLY WATER}

An additional source of information avallable for each wastestream is tile concentration of given chemical species in the water supplied to the facility. Facility water supplies can be broken into three maill categorles. "Raw" water is generally used for process cooling water throughout the Hanford Site; this water is essentially Columbla River water. "Sanitary" water is also used by many faclitities for processing or cooling; this watar is columbla River or well water which has been treated as needed to render it potable. The treatment used generally includes chlorination. Variations in constituent concentrations across the site can be attributed in part to this treatment. Steam is generated in several boller plants around the site using water which is treated (e.g., de-chlorination, ion exchange, de-aeration) prior to introduction to the boilers.

Both raw and sanitary water supplies have been analyzed in the past in vaitious locations throughout the Hanford Site. In particular, sanitary water is analyzed frequently for compliance with federally mandated drinking water standards. Historical data avallable on sanitary water supplies have been used to develop a means for screening facility sample data for compounds which are likely to be present in! a facility waste stream due to their presence in the factlity water supply.

Most of the data avaflable is for santtary water; analytical results for the pertod from 1985 to 1988 have been used to develop a screening test in a manner similar to that previously described for biank data. It is recognized that a screening level based upon average sanitary water data is not strictly indicative of the level of a contaminant that would be present in a facility water supply on the day that a wastewater sample is taken. However, it is also true that a sample of facility supply water taken the same day as the wastewater sample may not be strictly indicative of the actual coricentration of a constituent in the water supply making up the waste discharge; this difference would be caused by such factors as factlity piping holdup. In such cases, an average value is the most appropriate representation.

Raw water data avallable for the 200 West Area and 300 Area indicate that fluoride levels present in raw water are within the same magnitude as that seen in sanitary water; based on this comparison, the fluoride screening levels developed from sanitary water data have also been applied to streams containing raw water. The threshold values for mercury, carbon tetrachloride, and toluene are based upon the detection limits for these cunstituents in analyses of santtary water performed by the Hanford Environmental Health Foundation (HEHF). The chloroform data cannot be applied for streams composed of raw water.

To perform this sample screening for purposes of listed waste evaluations, the following protocol was applited:

1. A review of chemical inventortes and material management procedures at the facllity was performed to evaluate potential sources of the detected constituent. 
2. Individual sample results were compared (if applicable) to santtary water data avallable for the $100,200,300$, or 400 areas. Sample results less than the upper 1 imit of the one-sided $90 \% \mathrm{CI}$ value for sanitary water were not considered in the designation of the wastestream.

3. Sample results were compared to the detection 1 imit for "non-detected" species in sanitary water data. Sampie results less than this detection limit were not considered in the designation of the wastestream.

Based upoi this protocol, individual sample data for species commonly found in Hanford water supplies which were less than the threshold values in Table 5-3 were not considered in the listed waste portion of the waste designation procedure when no source of the detected constituent was identiffed. All validated data (see Section 3.2) were used in the quantitative aspects of the designation procedure.

\subsubsection{Discarded Chemical Product}

A wastestream was considered regulated as a discarded chemical product (WAC 173-303-081) if tt contained a commerclal chemical product 1 isted in WAC 173-303-9903 and met one of the following criteria.

- The listed constituent was the sole active ingredient in a commercial chemical product that had been discarded. Commercial chemical products which, as purchased, contained two or more active ingredients were not designated as discarded chemical products. Products that contained nonact tve components such as water, however, were designated if the sole active ingredient in the mixture was iisted in WAC 173-303-9903.

- The constituent resulted from a spill of an unused commercial chemical product. A spill of a listed chemical product would cause a wastestream to be designated only if the discharge was routine. The approach taken in the attached addenda was that the current wastestream would not be designated unless a review of prevtous spill events indicated that the splils were predictable, systematic events which were ongoing or were reasonably anticipated to occur in the future. For purposes of this report, the evaluation of this criterion was based upon a review of spill data that were reported in the Waste Stream Characterization Report (WHC 1989). 
Table 5-3. Santtary Water Threshold Values.

\begin{tabular}{|c|c|c|c|c|}
\hline Constytuent & $\mathrm{N}$ & Average & $\begin{array}{l}\text { Star Jard } \\
\text { Devtation }\end{array}$ & Threshold Value \\
\hline $\begin{array}{l}\text { For } 100-N \text { Area Facilities: } \\
\text { Chloroform } \\
\text { Toluene } \\
\text { Mercury } \\
\text { Ionic Fluoride }\end{array}$ & $\begin{array}{l}5 \\
0 \\
0 \\
4\end{array}$ & $\begin{array}{l}21 \\
<0.4 \\
<0.5 \\
138\end{array}$ & $\begin{array}{l}4 \\
\because- \\
\ddot{4} 1\end{array}$ & $\begin{array}{l}30 \\
0.4 \\
0.5 \\
234\end{array}$ \\
\hline $\begin{array}{l}\text { For 100-D Area Facilities: } \\
\text { Chloroform } \\
\text { Toluene } \\
\text { Mercury } \\
\text { Ionic Fluoride }\end{array}$ & $\begin{array}{l}5 \\
0 \\
0 \\
4\end{array}$ & $\begin{array}{l}16 \\
<0.4 \\
<0.5 \\
118\end{array}$ & $\begin{array}{l}10 \\
\cdots \\
21\end{array}$ & $\begin{array}{r}37 \\
0.4 \\
0.5 \\
167\end{array}$ \\
\hline $\begin{array}{l}\text { For } 200 \text { Area Facilities: } \\
\text { Chioroform } \\
\text { Mercury } \\
\text { Ionic Fluoride } \\
\text { Carbon Tetrachloride }\end{array}$ & $\begin{array}{l}5 \\
0 \\
4 \\
0\end{array}$ & $\begin{array}{l}22 \\
<0.5 \\
108 \\
<0.4\end{array}$ & $\begin{array}{l}13 \\
15 \\
15\end{array}$ & $\begin{array}{c}50 \\
0.5 \\
143 \\
0.4\end{array}$ \\
\hline $\begin{array}{l}\text { For } 300 \text { Area Facilities: } \\
\text { Chloroform } \\
\text { Mercury } \\
\text { Ionic Fluoride }\end{array}$ & $\begin{array}{l}5 \\
0 \\
4\end{array}$ & $\begin{array}{c}34 \\
<0.5 \\
196\end{array}$ & $\begin{array}{l}20 \\
\cdots . \\
1.9\end{array}$ & $\begin{array}{c}77 \\
0.5 \\
241\end{array}$ \\
\hline $\begin{array}{l}\text { For } 400 \text { Area Factlities: } \\
\text { Chloroform } \\
\text { Mercury } \\
\text { Ionic Fluoride }\end{array}$ & $\begin{array}{l}4 \\
0 \\
1\end{array}$ & $\begin{array}{c}1.9 \\
<0.5 \\
0.33\end{array}$ & $\begin{array}{l}0.3 \\
\therefore- \\
\therefore\end{array}$ & $\begin{array}{l}2.6 \\
0.5 \\
0.33\end{array}$ \\
\hline
\end{tabular}

All values (but $N$ ) in ppb.

$N=$ Number of detected results for organtcs; number of avatlable annual averages for inorganics.

Data for this table was compiled using data for sanitary water provided in Hanford Environmental Health Foundation Water Qual ity Survelliance Reports. Data for chloroform are for 1988 and 1989; data for other organics are from 1987 and 1988. Data for inorganics are annual average values from 1985 through 1988. 
- The constituent resulted from discarding residue from cleanup of a spll1 of an unused commerctal chemical product itsted in WAC 173-303-9903. A wastestream const ttuent that had been used in a process and then released to the wastestream was not considered a discarded chemical product. Off-specification, unused chemicals, and chemicals that had exceeded a shelf 1 ife but had not been used were considered discarded chemical products when not disposed of in accordance with the regulations.

\subsubsection{Dangerous Waste Sources}

A 1ist of dangerous waste sources (WAC 173-303-082) is contained in WAC 173-3C3-9904. This 1ist is divided into three categories: nonspecific sources, specific sources, and state sources. The specific sources 1 ist is aimed primarlly at certain industries (t.e., pesticide production, inorganic pigment production, organic chemical production). The nonspecific sources list includes wastestreams generated by a wide variety of industries. The state sources category addresses wastes generated from the salvaging, rebullding, or discarding of capacitors and transformers that contain PCB.

In evaluating whether or not a stream should be designated as a 1 isted waste, it was important to consider all sources which may have contributed to the stream. This made it necessary to review not only the chemicals used in a process to determine whether a 1 isted waste was being generated but also any feed streams into a particular process to determine whether processing of the matertal resulted in the generation of a 1 isted waste. The EPA "derived from" rule requires that a wastestream be designated as a 11 sted waste if it has been in contact with a listed waste, even if the 1 isted constituent cannot be detected in the stream. For example, some waste in the double-shell tanks is considered a listed waste. If this waste was subjected to treatment, any other stream which contacted this waste could subsequentiy become a listed waste. This analysis would also be extended to a steam condensate stream if leakage of the listed waste into the condensate stream were occurring.

In the attached addenda, the level of radioactivity in the wastestream was used as an indicator of the possibility of material from a leak or spill of a listed waste source. The comparison to vartous screening values (SV) (see Section 4.1) was used here to determine if a leak or spili had occurred. If the comparison indicated that the radionuclide levels were above the SVs, the possibility that a leak or splll entered the wastestream and the source of the radioactivity was evaluated. In this case the SVs were used as comparative values for purposes of standardizing background data.

\subsection{DANGEROUS WASTE CRITERIA}

An effluent stream was designated as regulated under WAC 173-303 as a dangerous waste if it qualified as one of the following: (1) a toxic dangerous waste (WAC 173-303-101), (2) a persistent dangerous waste (WAC 173-303-102), or (3) a carcinogentc dangerous waste (WAC 173-303-103). 
The methodology utillyed in the designation procedure for combining inorganic lons to form chemical substances necessary to evaluate this criterta is descrlbed in Wastestream Designation of Liquid Effluent Analytical Data (WHC 1990b). If this conservative procedure tentatively identified a dangerous waste, a process evaluation was conducted to determine if the assumptions contained in the procedure were appropriate.

\subsubsection{Toxic Dangerous Waste}

To determine if an effluent stream qualified as a toxic dangerous waste (WAC 173-303-101), the following test was applied to the sampling clata:

- Multiple samples were collected and analyzed from the wastestream.

- The upper 1 imit of the 90\%CI was calculated for each analyte in the wastestream.

- Substances were formulated from the analytical data.

NOTE: This step was required for inorganic analytes because it was not possible to complete the evaluation based on the concentration of cations and antons. This methodology is described in the Wastestream Designation of Liquid Effluent Analytical Data report (WHC 1990b) and is based on an evaluation of the most toxic substances that can exist in an aqueous environment under normal temperatures and pressures.

- Toxic categories were assigned to the substances detected or, in the case of inorganics, postulated to be in the wastestream.

- The percent equivalent concentration (EC\%) for each substance was calculated.

- The resuiting EC\% was summed.

- The wastestream was designated as a toxic dangerous waste if the EC\% was greater than $0.001 \%$, per WAC 173-303-9906.

\subsubsection{Persistent Dangerous Waste}

To determine if an effluent stream qualified as a persistent dangerous waste (WAC 173-303-102), the following test was applied to the sampling data:

- Multiple grab samples of the wastestream were collected.

- A determination was made as to which substances in the wastestream were halogenated hydrocarbons (HH) and which were polycyclic aromatic hydrocarbons (PAH). 
- The upper limit of the $90 \%$ CI was determined for the substances of interest.

- The weight percent contribution for $H H$ and $\mathrm{PAH}$, were calculated separately.

- The resulting weight percent for each $\mathrm{HH}$ and PAH were summed.

- The wastestream was designated as persistent if the weight percent contribution of the HH was greater than $0.01 \%$ or if the weight percent contribution of the PAH was greater than $1.0 \%$, in accordance with WAC 173-303-9907.

\subsubsection{Carcirogenic Dangerous Waste}

To determine if an effluent stream qualified as a carcinogenic dangerous waste, the following test was applied to the sampling data:

- Multiple grab samples of the wastestream were collected.

- The upper limit of the $90 \%$ CI was determined for the substances of interest.

- Substances were formulated from the analytical data.

NOTE: This step was required for inorganic analytes because it was not possible to complete the evaluation based on the concentration of cations and anions. This methodology is described in WHC (1990b) and is based on an evaluation of the carcinogenic substances that exist in an aqueous erivironment under normal temperatures and pressures.

- A determination was made as to which substances in the wastestream were carcinogenic according to the International Agency for Research on Cancer.

- The weight percent concentration was calculated for each carcinogen.

- The resulting weight percent was summed.

- The wastestream was designated as carcinogenic if any of the positive (human or anima1) carcinogens were above $0.01 \%$ or if the total concentration was above $1.0 \%$ for any positive and suspected (human or animal) carcinogens. 


\subsection{DANGEROUS WASTE CHARACTERISTICS}

An effluent stream was designated as regulated under WAC 173-303 as a dangerous waste if it qualified as one of the following: (1) ignitable (WAC 173-303-090[5]), (2) corrosive (WAC 173-303-090[6]), (3) reactive (WAC 173-303-090[7]), or (4) extraction procedure (EP) tcxic (WAC 173-303-090[8]).

\subsubsection{Ignitability}

Since July 1989 (i.e., including all new data) flashpoint testing has been routinely requested on all of the liquid effluent samples. All tested samples reached the boiling temperature of water without igniting.

Flashpoint testing was not performed on the initial samples collected from the wastestreams before July 1989 (i.e., most old data). However, an ignitability index can be calculated for the sample based on the sum of the percent concentrations of all ignitabla contributors in the wastestream. Pure substances with a flasinpoint $<140^{\circ} \mathrm{F}$ were considered ignitable. Based upon Best Professional Judgmeni (BPJ), samples which exhibited an ignitability index below $1 \%$ were not considered ignitable.

\subsubsection{Corrosivity}

An effluent was considered regulated if the stream exhibited a $\mathrm{pH}$ of $\leq 2.0$ or $\geq 12.5$. The comparison to this characteristic was based on the lower $1 \mathrm{imit}$ of the one-sided $90 \% \mathrm{CI}$ for a stream exhibiting a $\mathrm{pH}<7.25$ and the upper limit of the one-sided $90 \%$ I for streams exhibiting $\mathrm{pH} \geq 7.25$.

\subsubsection{Reactivity}

The criteria in WAC 173-303-090(7) for reactivity applicable to liquid effluent streams is the inspection for sufficient content of cyanide or sulfide which, under corrosive conditions, would threaten human health or the environment.

A recent revision to the SW-846 procedure (EPA 1986) provides more quant itative "indicator" levels for cyanide and sulfide. These indicator levels for hydrogen cyanide and hydrogen sulfide are $250 \mathrm{mg} / \mathrm{kg}$ and $500 \mathrm{mg} / \mathrm{kg}$, respectively. If the upper $90 \%$ CI for the compounds in the effluent streams were below these level's, the streams were considered not regulated based on reactivity.

For samples collected before July 1989, total cyanide and total sulfide measurements were used to evaluate reactivity. The revised SW-846 procedure was utilized for samples collected after July 1989. 


\subsubsection{Extraction Procedure Twicity}

An effluent stream was considered regulated under the EP toxicity criteria (WAC 173-303-090[8]) if the upper 1imit of the $90 \%$ CI for the specific compounds in the wastestream exceeded the EP toxicity concentration limits. The SW-846 procedure provides specific guidance for obtaining data results for comparison against the EPA toxicity limits. Until July 1989, total compound concentrations were compared against the limits, resulting in a more conservative designation. Since that time, the sampling data have been collected and analyzed according to the EP toxicity method specified in SW-846.

\subsection{PROPOSED DESIGNATION}

The proposed designations contained in 24 SSRs were based on a combination of process knowledge and sample data collected between October 1989 and March 1990. A similar process was used for the nine effluents lacking recent data by using the most current data available. In all cases process knowledge was used to determine if discarded chemical products or 1 isted sources entered the wastestream. Sample data were used to determine the characteristic and crite a designations that involve quantitative threshold levels. The proposed dignations of the effluents were arrived at based upon Westinghouse Hanford evaluation of stream-specific data and are subject to Ecology concurrence. 
WHC-EP-0342

\subsection{ACTION PLAN}

This chapter has been set aside in each SSR to address recommendations for future waste characterization tasks for the liquid effluents that are within the scope of the Liquid Effluent Study Project Plan (WHC 1990c). The final scope and schedule for any recommended tasks are subject to negotiation between Ecology, the EPA, and DOE. An implementation schedule for the completion of these tasks will consider other compliance actions already underway as part of the Tri-Party Agreement (Ecology et a1. 1989). A11 effluent monitoring and sampling will be conducted according to DOE Order 5400.1 (DOE 1988).

New, or currently inactive, effluent or configurations would need to be characterized upon startup or restart. This generic need is stated in Section 6.1 of each addendum. In addition, during the process of reviewing the current characterization data for each active effluent or configuration, other opportunities to augment process knowledge and/or reinforce the sample data may have occurred. These tasks, especially if related to any recognized technical issues, problems, or deficiencies related to the Liquid Effluent Study Project Plan, are highlighted in Section 6.2 of each addendum. It should be noted that other site programs will address many of these needs. Therefore, the action plans provided in each SSR should be viewed as preliminary.

Section 6.1 in each SSR 1 ists the process configurations that were sampled, consistent with the discussion of configurations presented in Section 2.0. Major configurations that were not sampled are also identified. A recommendation is made to collect irandom samples from any unsampled configurations that were active during the period. Any configurations that were not active will be sampled upon startup. Further recommendations are made, where relevant, to collect random samples from the effluents which were inactive during the sampling period. (Some effluents, such as the 209E Reflector Water, which are not expected to ever be reactivated may simply state that, "No future samples are warranted for this effluent.")

Section 6.2 in each SSR is based on the discussion in Section 2.0 on the flow diagram or schematic. Recommendations are made to correct any major deficiencies in the sampling program (e.g., a contributor, not a configuration, to the stream was not sampled or the volume of the discharge is not monitored). A statement is made, as appropriate, if the samples collected are not considered to be representative of the types of constituents present in the contributing wastestreams. Such a statement would require a plausible explanation for all the potential listed constituents identified in the effluent. 
WHC-EP-0342

\subsection{REFERENCES}

APHA, AWWA, and WPCF, 1985, Standard Methods for the Examination of Water and Waterworks, 16th Ed., American Public Health Association, American Water Works Association, and Water Pollution Control Federation, Washington, D.C.

ASTM, 1986, 1986 Book of ASTM Standards, Amertcan Soctety of Testing and Materials, Philadelphia, Pennsylyania.

Camprehensive Environmental Response, Compensation, and Liability Act of 1980, as amended, Public Law 96-510, 94. Stat. 2767, 42 USC 9601 et seq.

DOE, 1988, General Environmental Protection Program, DOE Order 5400.1, U.S. Department of Energy, Washington, D.C.

Ecology, 1989, Dangerous Waste Regulations, Washington Administrative Code (WAC) 173-303, Washington State Department of Ecology, Olympia, Washington.

Ecology, EFA, DOE, 1989, Hanford Federal'Facility Agreement and Consent Order, Washington State Department of Ecology, U.S. Environmental Protection Agency, U.S. Department of Energy, 01ympia, Washington.

EPA, 1985, "Protection of Environment", Title 40, Code of Federal Regulations, U.S. Environmental Protection Agency, Office of the Federal Register, 40 CFR 141, 1985, EPA National Primary Drinking Water Standards, National Archives and Records Administration, Washington, D.C.

EPA, 1986a, Test Methods for Evaluating Solid Waste: Physical and Chemical Methods, SW-846, 3rd ed., U.S. Environmental Protection Agency, Washington, D.C.

EPA, 1986b, Federal Register, Vol. 51, p. 34859, "Water Pollution Control; National Primary Drinking Water Regulations; Radionuclides; Advance Notice of Proposed Rulemaking", Sept. 30, 1986.

EPA, 1988a, Laboratory Data Validation Functional Guidelines for Evaluating Orgalics Analyses, EPA 0508, Prepared for Hazardous Site Evaluation Division of the U.S. Environmental Protection Agency, Washington, D.C.

EPA, 1988b, Protection of Environment, Title 40, Code of Federal Regulations, U.S. Environmental Protection Agency, Office of the Federal Register, 40 CFR 143, 1988, EPA National Secondary Drinking Water Standards, Nitional Archives and Records Administration, Washington, D.C.

EPA, 1y89, Federal Register, Vol. 54, p. 22062, "EPA Proposed National Primary and Secondary Drin':ing Water Regulations". 
EPA, 1990, Federal Register, Vo1. 55, p. 30370, "Proposed Rules: National Primary and Secondary Drinking Water Regulations; Synthetic Organic Chemicals and Inorganic Chemicals".

Lawrence, M. J., 1989, Liquid Effluent Study, (External Letter 8902106 to C. Gregoire, Washington State Department of Ecology; and R. Russe11, U.S. Environmental Protection Agancy, May 13, 1989), U.S. Department of Energy-Richland Operations Office, Richland, Washington.

Millikin, E.J., 1989, 1989 Annual Status Report of the Plan and Schedule to Discont inue Disposal of Contaminated Liquids into the Soll Columr at the Hanford Site, WHC-EP-0196-2, Westinghouse Hanford Company. Richland, Washington.

SARA, Superfunded Amendments and Reauthorization Act of 1986, Public Law 99-499, 100 Stat., 1613, 42 USC 11001 et seq.

Somers, S., 1989, Hanford Sanitary Water Quality Surveillance, CY 1988, HEHF-74, Hanford Environmental Health Foundation, Richland, Washington.

Somers, S., 1988, Hanford Sanitary Water Quality Surveillance, CY 1987, HEHF-71, Hanford Environmental Health Foundation, Richland, Washington.

Somers, S., 1987., Hanford Sanitary Water Quality Surveillance, CY 1986, HEHF-59, Hanford Environmental Health Foundation, Richland, Washington.

Thurman, P. A., 1990, Hanford Sanitary Water Quality Surveillance, Cr 1.989, HEHF-76, Hanford Environmental Health Foundation, Richland, Washingtion.

WHC, 1988, Environmental Compliance, WHC-CM-7-5, Regulatory Compliance, Westinghouse Hanford Company, Richland. Washington.

WHC, 1989, Waste Stream Characterization Repurt, WHC-EP-0287, Volumes 1 through 4, Westinghouse Hanford Company, Richland, Washington.

WHC, 1990a, Liquid Effluent Study Project Plan, WHC-EP-0275, REV. 2, Westinghouse Hanford Corlupany, Richland, Washington.

WHC, 1990b, hiastestream Designation of Liquid Effluent Analytical Data, WHC-EP-0334 Draft, Westinghouse Hanford Company, Richland, Washington.

WHC, 1990C, Liquid Effluent Study Characterization Data, WHC-EP-0355, Westinghouse Hanford Company, Richland, Washington.

WHC, 1990d, Liquid Effluent Stuay Final Project Report, WHC-EP-0367, Westinghouse Hanford Company, Richland, Washington. 
WHC-EP-0342

\section{APPENDIX A--SAMPLING SPECIFICATIONS}

$$
A-1 / 0
$$


Table A-1. Sampling Spectfications. (Sheet 1 of 2)

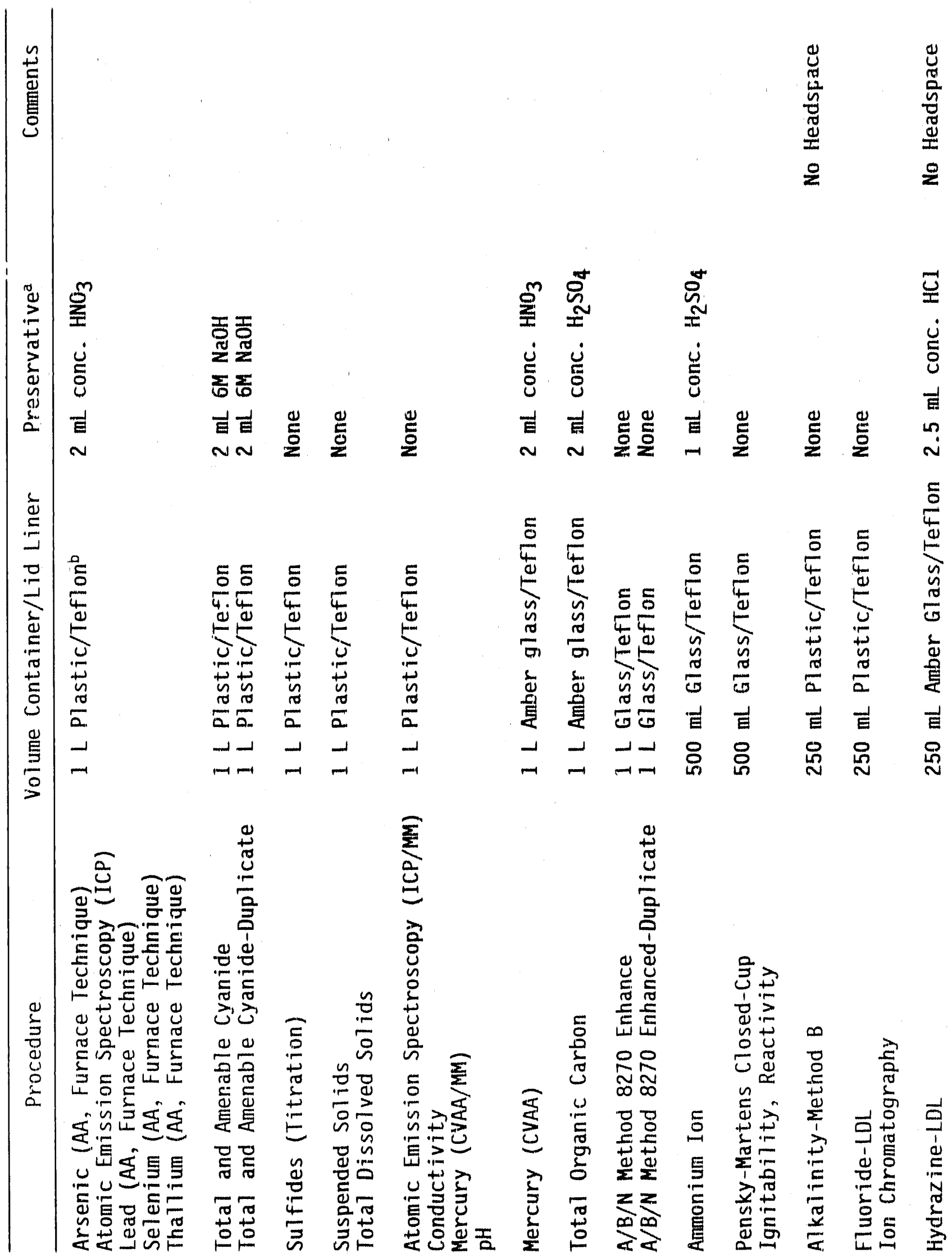


Table A-1. Sampling Specifflcations, (Sheet 2 of 2)

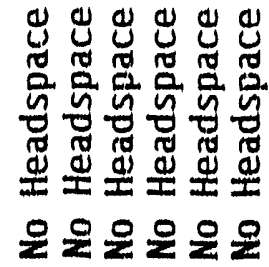

준운운운유

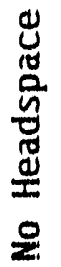

畜

تئئ

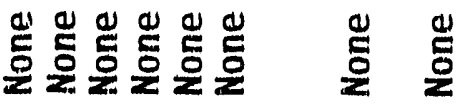

目曷圆圆园

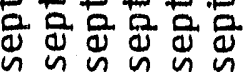

등드옹드

$4454 \frac{4}{4} 4$

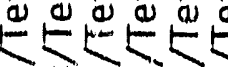

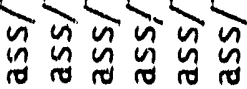

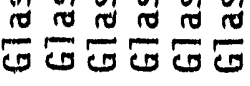

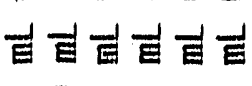
앙앙웡ㅇㅇㅇ

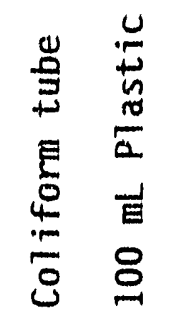

$\underline{n}$

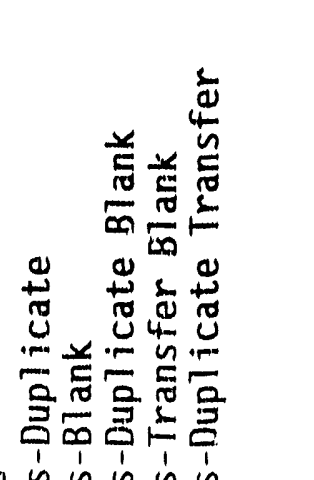

氙氖出出出

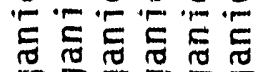

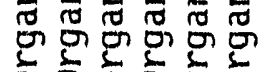

क 00000

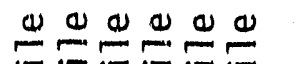

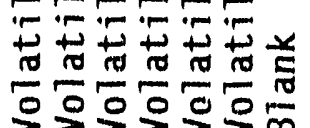

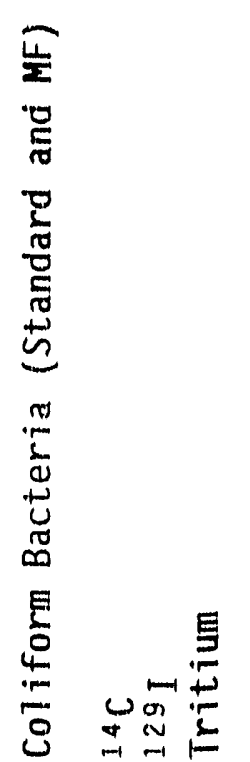

A-4

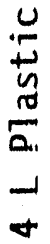

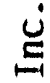

芯

ه

茪

$\stackrel{0}{0}$

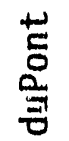

르 हिं

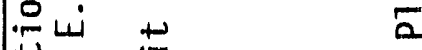

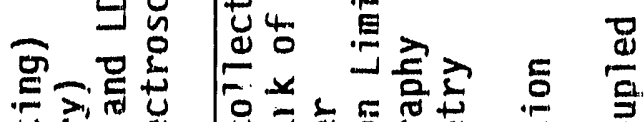
I

St证至

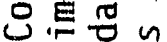

的它

오ㅇㅝㅛ

ar in

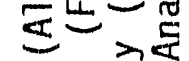

纭号志京

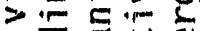

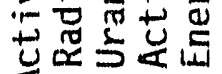

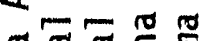

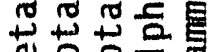

岗に栆 
WHC - EP- 0342

\section{APPENDIX B-METHODS OF ANALYSIS}

B-1/2 
WHC-EP-0342

Table B.1. Methods of Analysis. (sheot 1 of 2)

\begin{tabular}{|c|c|c|}
\hline Code & Analytical Mothud & Reference \\
\hline $\begin{array}{l}\text { ABN } \\
\text { AEA } \\
\text { AEA } \\
\text { AEA } \\
\text { AEA } \\
\text { ALPHA } \\
\text { ALPHA-Ra } \\
\text { BETA } \\
\text { BETA } \\
\text { COLIF } \\
\text { COLIFMF } \\
\text { COND -FId } \\
\text { COND-Lab } \\
\text { CVAA } \\
\text { CVAA/M } \\
\text { DIGC } \\
\text { DIMS } \\
\text { DSPEC } \\
\text { DTITRA } \\
\text { FLUOR } \\
\text { GEA } \\
\text { GFAA } \\
\text { GFAA } \\
\text { GFAA } \\
\text { GFAA } \\
\text { IC } \\
\text { ICP } \\
\text { ICP/M } \\
\text { IGNIT } \\
\text { ISE } \\
\text { ISE } \\
\text { LALPHA } \\
\text { LEPD } \\
\text { LSC } \\
\text { LSC } \\
\text { LTOX } \\
\text { PH-FId } \\
\text { PH-Lab } \\
\text { SPEC } \\
\text { SPEC } \\
\text { SSOLID } \\
\text { TC } \\
\text { TDS } \\
\text { TEMP-FId }\end{array}$ & 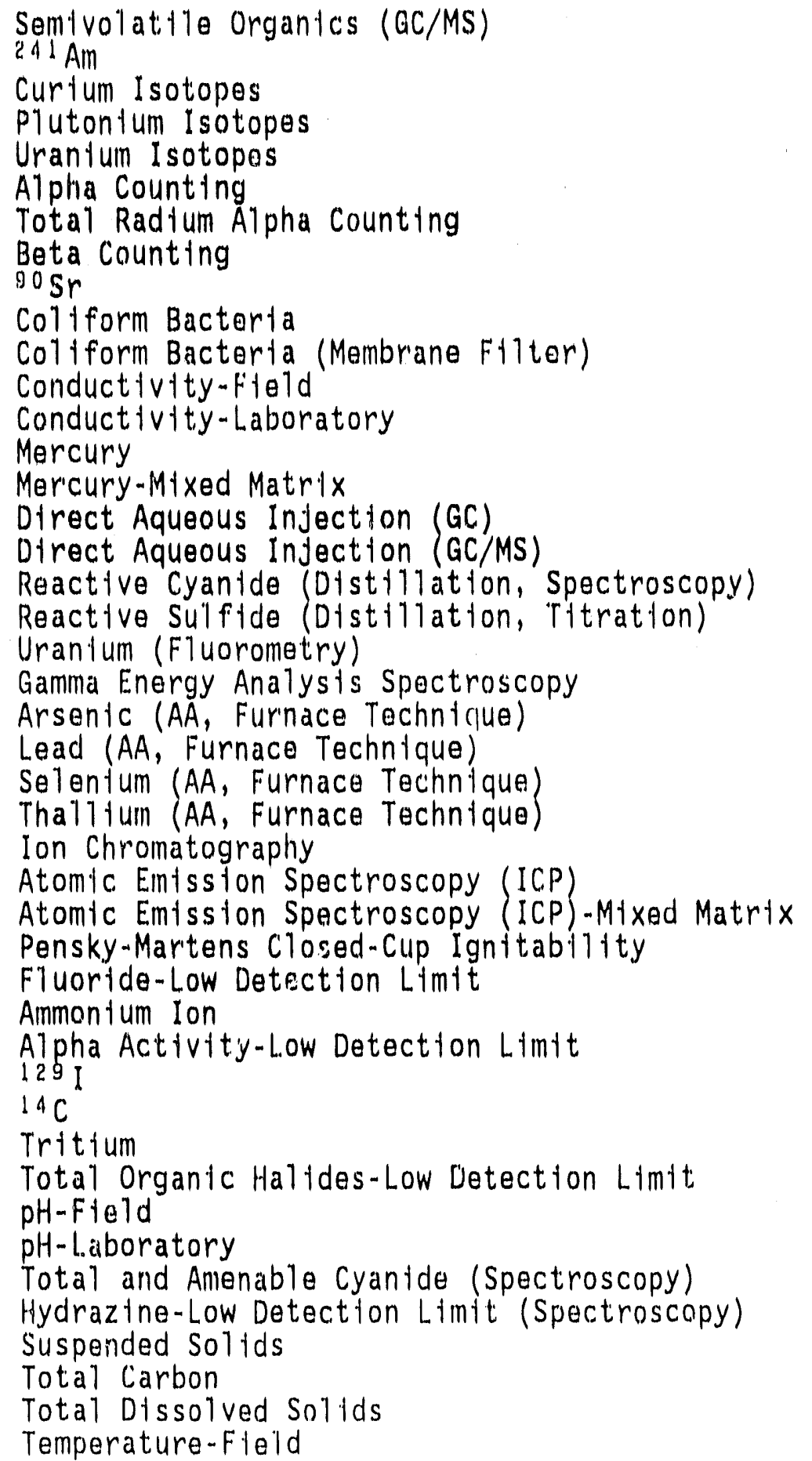 & $\begin{array}{l}\text { USEPA-8270 } \\
\text { UST-20Am01 } \\
\text { UST-20Am/CmO1 } \\
\text { UST-20PU01 } \\
\text { UST-20U01 } \\
\text { EPA-680/4-75/1 } \\
\text { ASTM-D2460 } \\
\text { EPA-680/4-75/1 } \\
\text { UST-20SrO2 } \\
\text { USEPA-9131 } \\
\text { USEPA-9132 } \\
\text { ASTM-D1125A } \\
\text { ASTM-D1125A } \\
\text { USEPA-7470 } \\
\text { USEPA-7470 } \\
\text { UST-70D1GC } \\
\text { "USEPA-8240" } \\
\text { USEPA-CHAPTER } 7 \\
\text { USEPA-CHAPTER } 7 \\
\text { ASTM-D2907-83 } \\
\text { ASTM-D3649-85 } \\
\text { USEPA-7060 } \\
\text { USEPA-7421 } \\
\text { USEPA-7740 } \\
\text { USEPA-7841 } \\
\text { EPA-600/4-84-01 } \\
\text { USEPA-6010 } \\
\text { USEPA-6010 } \\
\text { USEPA-1010 } \\
\text { ASTM-D1179-80-B } \\
\text { ASTM-D1426-D } \\
\text { EPA-680/4-75/1 } \\
\text { UST-20102 } \\
\text { UST-20C01 } \\
\text { UST-20H03 } \\
\text { USEPA-9020 } \\
\text { USEPA-9040 } \\
\text { USEPA-9040 } \\
\text { USEPA-9010 } \\
\text { ASTM-D1385 } \\
\text { SM-208D } \\
\text { USEPA-9060 } \\
\text { SM-208B } \\
\text { LOCA1 } \\
\text { LST }\end{array}$ \\
\hline
\end{tabular}


Table B.1. Methods of Analysis. (sheet 2 of 2)

\begin{tabular}{|c|c|c|}
\hline Code & Analytical Method & Reference \\
\hline $\begin{array}{l}\text { TITRA } \\
\text { TITRA } \\
\text { TOC } \\
\text { TOX } \\
\text { YOA }\end{array}$ & $\begin{array}{l}\text { Alkalintty-Method B (Titration) } \\
\text { Sulfides (Titration) } \\
\text { Total Organtc Carbon } \\
\text { Total Organtc Haltdes } \\
\text { Volatile Organtcs (GC/MS) }\end{array}$ & $\begin{array}{l}\text { ASTM-D1067B } \\
\text { USEPA-9030 } \\
\text { USEPA-9060 } \\
\text { USEPA-9020 } \\
\text { USEPA-8240 }\end{array}$ \\
\hline
\end{tabular}

The code is used in the data tables which appear in each addendum

Analytical Method Acronyms:

$A A$. atomic absorption spectroscopy.

GC - gas chromatography.

MS * mass spectrometry.

ICP = Induct tvely-coupled plasma spectroscopy.

References:

ASTM- - 1986 Annual Book of ASTM Standards, (ASTM 1986).

EPA- Varlous methods of the U.S. Environmental Protection Agency, Washington, D.C.

UST--Methods of the United States Testing Company, Incorporated, Rtchland, Washingtion.

SM--Standard Methods for the Examination of Water and Wastewater, (APHA, AWWA, and WPCF 1985).

USEPA--Test Methods for Evaluating Solid Waste Physical/Chemical

Methods, (EPA 1986a). 
WHC - EP- 0342

\section{APPENDIX C}

SCREENING VALUES USED IN EFFLUENT COMPARISONS

c. $-1 / 2$ 
Table C-1. Screening Values (SV) Used in Effluent Compartsons. [Chemtcal SV in $\mathrm{mg} / \mathrm{L}$; Radionuclide SV in $\mathrm{pC} / \mathrm{L}$ ] (sheet 1 of 2)

\begin{tabular}{|c|c|c|c|c|c|c|}
\hline Analyte & PMCLa & PSMCLa & $M C L^{a}$ & SMCLa & SV1a & $S V 2^{b}$ \\
\hline Aluminum & $\ldots$ & $0.05^{\circ}$ & $\ldots$ & . - & 0.050 & $\ldots$ \\
\hline Arsentc & $\ldots$ & 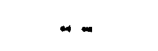 & $0.05^{d}$ & $\omega$ & $0.05 d$ & $\cdots$ \\
\hline Barium & $5^{0}$ & $\ldots$ & $1^{d}$ & - & 50 & $\cdots$ \\
\hline Bery 11 tum & $0.001^{\mathrm{e}}$ & $\cdots$ & $\therefore$ & $\cdots$ & $0.001 \mathrm{e}$ & $\ldots$ \\
\hline Cadmium & $0.005^{\circ}$ & $\cdots$ & $0.01^{d}$ & $\cdots$ & 0.0050 & $\cdots$ \\
\hline chloride & - & $\cdots$ & $\because$ & $250^{f}$ & $250 p$ & $\cdots$ \\
\hline Chromium & $0.1^{0}$ & $\cdots$ & $0.05^{d}$ & $\cdots$ & 0.10 & $\ldots$ \\
\hline Copper & $\ldots$ & $\cdots$ & - & $1^{f}$ & $1^{p}$ & $\cdots$ \\
\hline Cyantde & $0.2^{\theta}$ & $\ldots$ & $\cdots$ & $\cdots$ & $0.2^{\circ}$ & $\cdots$ \\
\hline Fluortde & $\cdots$ & $\cdots$ & $4^{d}$ & $2^{f}$ & $2^{f}$ & $\cdots$ \\
\hline Iron & - & -- & - & $0.3^{f}$ & $0.3^{f}$ & $\cdots$ \\
\hline Lead & $\cdots$ & $\cdots$ & $0.05^{d}$ & $\cdots$ & $0.05^{d}$ & $\cdots$ \\
\hline Manganese & $\cdots$ & $\cdots$ & $\cdots$ & $0.05^{f}$ & $0.05^{f}$ & $\cdots$ \\
\hline Mercury & $0.002^{\circ}$ & $\cdots$ & $0.002^{d}$ & $\cdots$ & $0.002^{\circ}$ & - \\
\hline Nickel & $0.1^{\mathrm{\theta}}$ & $\cdots$ & $=$ & -- & $0.1^{0}$ & $\cdots$ \\
\hline Nitrate & $45^{\circ}$ & $\cdots$ & $45^{d}$ & $\cdots$ & $45^{\circ}$ & $\cdots$ \\
\hline Nitrite & $4^{\circ}$ & $\cdots-$ & $\cdots$ & - & $4^{\circ}$ & $\cdots$ \\
\hline Sulfate & $500^{\circ}$ & $\cdots$ & $\cdots$ & $250^{f}$ & $250^{f}$ & $\ldots$ \\
\hline Tha11 tum & $0.002^{\mathrm{\theta}}$ & $\cdots$ & $\cdots$ & - & $0.002^{\circ}$ & $\ldots$ \\
\hline $\operatorname{linc}$ & $\ldots$ & - & $\cdots$ & $5^{f}$ & $5^{f}$ & $\cdots$ \\
\hline Bis (2-ethy1hexy1) & & & & & $\cdots$ & $\cdots$ \\
\hline phthalate & $0.004^{e}, g$ & - & $\cdots$ & $\ldots$ & $0.004^{e}, 9$ & - \\
\hline Bromodtchloromethane & -- & $\ldots$ & $0.1^{d, h}$ & $\cdots$ & $0.1^{\mathrm{d}}, \mathrm{h}$ & - \\
\hline Dichloromethane & $0.005^{\circ}$ & $-\infty$ & $\cdots$ & $\cdots$ & $0.005^{\mathrm{e}}$ & -- \\
\hline Toluene & $2^{\circ}$ & $0.04^{\circ}$ & $\cdots$ & $\cdots$ & $0.04 \mathrm{c}$ & $\ldots$ \\
\hline Trichloromethane & - & - & $0.1^{\mathrm{d}, \mathrm{h}}$ & $\cdots$ & $0.1 d, h$ & - \\
\hline Unkonwn & & & & & & - \\
\hline oxygenated PAH & $0.0002^{e, 1}$ & $\cdots$ & $\cdots$ & - & $0.0002^{\theta}, 1$ & - \\
\hline $\begin{array}{l}\text { Total Dissolved } \\
\text { Solids }\end{array}$ & $\ldots$ & & & $500 f$ & anf & $\cdots$ \\
\hline Alpha Activity & $\cdots$ & $\cdots$ & $15^{d}, j$ & 500 & $15^{d}$ & 30 \\
\hline Beta Activity & - & $\cdots$ & $\cdots$ & $\cdots$ & $\ldots$ & 1,000 \\
\hline $241 \mathrm{Am}$ & $4^{k}$ & $\cdots$ & $\cdots$ & $\ldots-$ & $4^{k}$ & 30 \\
\hline $144 \mathrm{Ce}$ & -- & - & $\cdots$ & $\cdots$ & $\ldots$ & 7,000 \\
\hline $242 \mathrm{Cm}$ & $\ldots$ & $\cdots$ & $\cdots$ & - & $\cdots$ & 1,000 \\
\hline $244 \mathrm{Cm}$ & -- & $\cdots$ & $\cdots$ & $\cdots$ & $\cdots$ & 60 \\
\hline $60 \mathrm{CO}$ & $200^{k}$ & $\cdots$ & - & $\cdots$ & $200^{k}$ & 5,000 \\
\hline $134 \mathrm{Cs}$ & $80^{k}$ & - & $\cdots$ & $\ldots$ & $80^{k}$ & 2,000 \\
\hline $137 \mathrm{Cs}$ & $100^{k}$ & - & - & -. & $100^{k}$ & 3,000 \\
\hline $14 \mathrm{C}$ & $3000^{k}$ & - & $\cdots$ & $\ldots$ & $3000^{k}$ & 70,000 \\
\hline${ }^{3} \mathrm{H}$ & $90,000^{k}$ & - & $\cdots$ & $\cdots$ & $90,000^{k}$ & $2 E+0 b^{\prime \prime}$ \\
\hline $129 I$ & $100^{k}$ & - & $\cdots$ & $\ldots$ & $100^{k}$ & 500 \\
\hline $54 \mathrm{Mn}$ & $3000^{k}$ & - & $\cdots$ & $\ldots$ & $3000^{k}$ & 50,000 \\
\hline $22 \mathrm{Na}$ & $500^{k}$ & $\cdots$ & $\cdots$ & $\ldots$ & $500^{k}$ & 10,000 \\
\hline
\end{tabular}


WHC-EP-0342

Table C-1. Screening Values Used in Effluent Comparisons. (sheet 2 of 2).

\begin{tabular}{|c|c|c|c|c|c|c|}
\hline Analyte & PMCLa & PSMCL ${ }^{a}$ & $M C L^{a}$ & SMCLa & $S V 1^{a}$ & $\mathrm{SV} 2^{\mathrm{b}}$ \\
\hline $210 \mathrm{pb}$ & - & - & -- & - & $\cdots$ & 30 \\
\hline $238 \mathrm{Pu}$ & - - & -. & -. & $\ldots$ & $\ldots$ & 40 \\
\hline $239,240 \mathrm{pu}$ & $40^{k} \cdot 1$ & $\ldots$ & -. & $\cdots$ & $40^{k}$ & 30 \\
\hline $228 \mathrm{Ra}$ & $5^{k}, m$ & .. & - & -. & $5^{k}$ & 100 \\
\hline $106 \mathrm{Ru}$ & $300^{k}$ & -- & - - & -. & $300^{k}$ & 6,000 \\
\hline $90 \mathrm{Sr}$ & $50^{k}$ & - & -- & - & $50^{k}$ & 1,000 \\
\hline $234 U$ & - & -- & -. & - & -. & 500 \\
\hline $235 U$ & $\ldots$ & - & -. & - & - & 600 \\
\hline $238 \mathrm{U}$ & -- & -- & -- & - & $\ldots$ & 600 \\
\hline
\end{tabular}

Notes:

The SV1 values represent the lower value between the primary or secondary MCLs (within each primary and secondary MCL subset, the most recently proposed MCLs are used to supersede existing values), where:

PMCL $=$ Proposed [Primary] Maximum Contaminant Leve]

PSMCL = Proposed Secondary Maximum Contaminant Level

$M C L=$ Maximum Contaminant Level

SMCL = Secondary Maximum Contaminant Level.

The often reported "MCL" for gross beta (of $50 \mu \mathrm{Ci} / L$ ) is not included here as it is not an actual $\mathrm{MCL}$ but merely a level indicating that detailed, radionuclide-specific analyses are needed.

b The SV2 are Derived Concentration Guides from WHC-EP-7-5, Environmental

Compliance (WHC 1988), Appendix A, Rev. 1, January 30, 1990, (the "Gross Alpha" DCG is used with the analyte "Alpha activity;" similarly for beta).

cFrom Federal Register, Vol. 54, p22062, "EPA Proposed National Primary and

Secondary Drinking Water Regulations," May 22, 1989 (EPA 1989).

dFrom 40 CFR 141, 1985, EPA National Primary Drinking Water Standards

(EPA 1985).

efrom Federal Register, Vo1. 55, p30370, July 25, 1990 (EPA 1990)). (Note that

when more than one number was proposed, used highest value.)

f From 40 CFR 143, 1988, EPA National Secondary Drinking Water Standards

(EPA 1988b).

gThe SV for di(ethylhexyl)phthalate is used with this analyte.

h The trihalomethane SV includes four compounds; only trichloromethane has been detected (with the exception of once for bromodichloromethane).

This Polycyclic Aromatic Hydrocarbon (PAH) SV is identified in (e) as being for benzo(a)pyrene. It is being used with the analyte "Unknown PAH".

jThis gross alpha SV is specified in (d) as excluding radon and uranium; and its being compared here with the analyte "Alpha activity".

kFrom Federal Register, Vo1. 51, p34859, "Water Pollution Control; National

Primary Drinking Water Regulations; Radionuclides; Advance Notice of Proposed Rulemaking", September 30, 1986 (EPA 1986b).

The analyte 239.240 $\mathrm{Pu}$ is being conservatively compared to the proposed $\mathrm{MCL}$

for $239 \mathrm{Pu}$, the only drinking water regulation-related value available. and $228 \mathrm{Ra}$.

"The analyte "228 Ra" is being compared against the SV for combined ${ }^{226} \mathrm{Ra}$ 

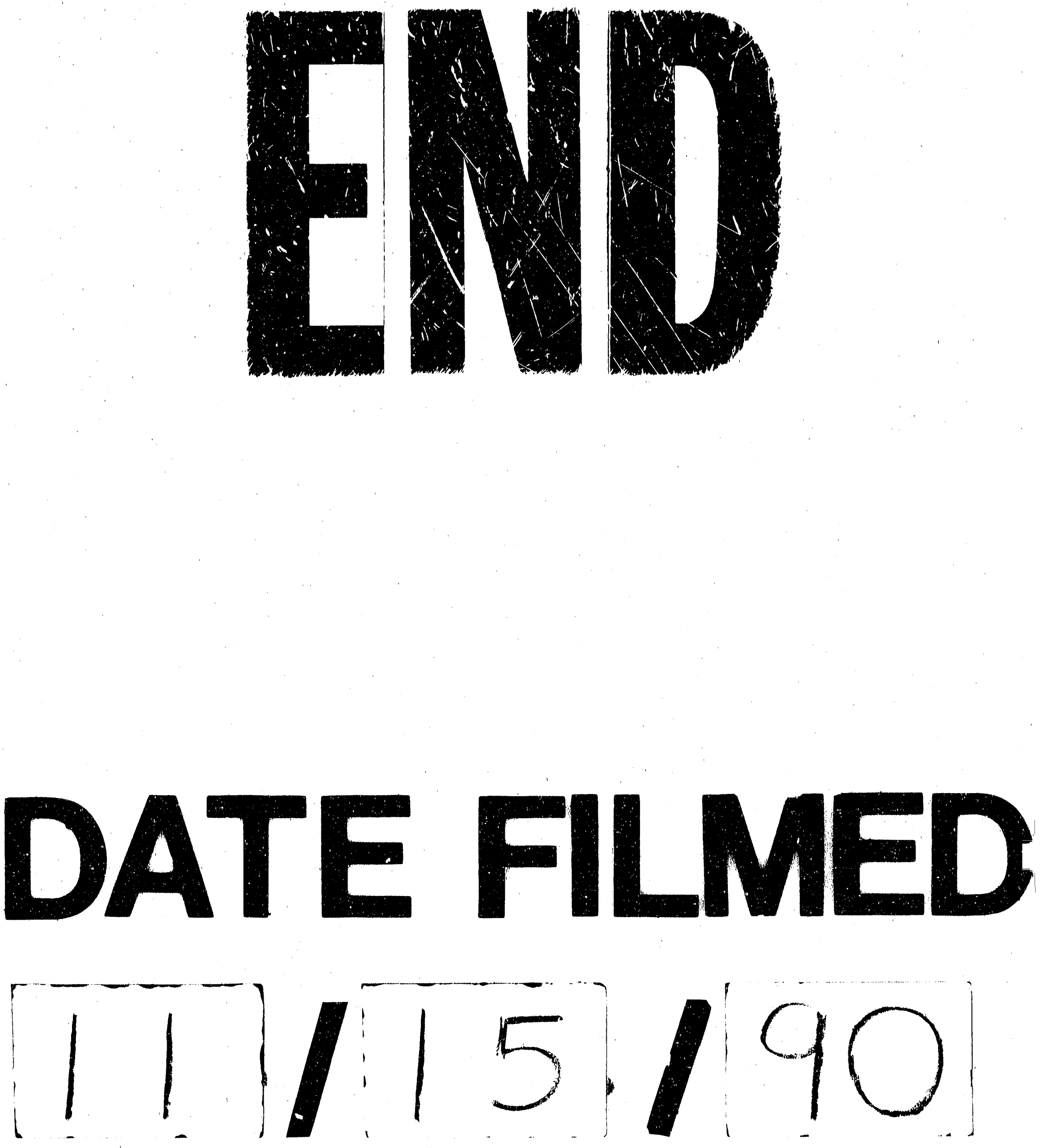
